\title{
PENGARUH DISIPLIN, MOTIVASI, DAN PELATIHAN TERHADAP KINERJA KARYAWAN DI PT KIC
}

\author{
Muhammad Bagja Sogiana \\ Bagja_sogi@yahoo.com
}

\begin{abstract}
ABSTRAK
Penelitian ini berjudul Pengaruh Disiplin, Motivasi, dan Pelatihan Terhadap Kinerja Karyawan di PT KIC. Masalah yang diangkat dalam penelitian ini adalah : untuk mengetahui, menjelaskan dan menganalisis Disiplin, Motivasi, dan Pelatihan Terhadap Kinerja Karyawan di PT KIC serta pengaruh parsial dan simultan Disiplin, Motivasi, dan Pelatihan Terhadap Kinerja Karyawan di PT KIC. Jumlah sampel yang diambil sebanyak 154 pegawai dengan teknik sampling jenuh. tesis ini diharapkan dapat memberikan sumbangan bagi pengembangan bidang manajemen khususnya manajemen sumber daya manusia. Metode penelitian yang digunakan penulis dalam penulisan ini menggunakan metode deskriptif dan verifikatif, dari hasil analisis data penelitian diperoleh beberapa kesimpulan sebagai berikut: (1) Disiplin Kerja pada PT KIC sudah sesuai aturan perusahaan, Motivasi pada PT KIC yang diberikan kepada karyawan sudah baik, Pelatihan pada PT KIC sudah berjalan dengan baik, dan Kinerja Karyawan pada PT KIC memiliki kinerja yang baik. (2) korelasi antara Disiplin, Motivasi, dan Pelatihan kerja secaraparsial terdapat hubungan yang sangat kuat, positif dan signifikan.(3) Pelatihan lebih banyak memberikan pengaruh terhadap Kinerja dibandingkan variabel Disiplin dan Motivasi. (4) Disiplin Kerja, Motivasi dan Pelatihan secara simultan berpengaruh positif dan signifikan terhadap Kinerja Karyawan sehingga Disiplin Kerja, Motivasi dan Pelatihan terhadap Kinerja Karyawan yaitu sebesar 0,761 atau $76,1 \%$
\end{abstract}

\section{Kata Kunci : Disiplin, Motivasi, Pelatihan Kerja, Kinerja}

\section{A. PENDAHULUAN}

Industri surfaktan di Indonesia masih terbatas, sementara itu surfaktan dibutuhkan dalam jumlah besar. Kebutuhan surfaktan Indonesia pada tahun 2015 adalah 495.000 ton, sekitar 45.000 ton masih diimpor dan diperkirakan jumlah impor tersebut setiap tahunnya terus berkembang. Perkembangan industri kosmetik, detergen, produk-produk perawatan diri semakin meningkat, dimana meningkatnya produk-produk tersebut mengakibatkan kebutuhan bahan aktif seperti surfaktan semakin meningkat pula. Surfaktan (surface active agent) merupakan salah satu oleokimia turunan yang merupakan senyawa aktif yang mampu menurunkan tegangan permukaan dan tegangan antaramuka suatu cairan. Perkembangan industri surfaktan semakin pesat dengan adanya perusahaan-perusahaan baru yang bergerak dibidang surfaktan. Melihat persaingan tersebut maka PT KIC merupakan perusahaan yang memproduksi surfaktan diperlukan suatu pengelolaan Sumber Daya Manusia (SDM) untuk dapat bersaing dengan perusahaan surfaktan lainya. 
Penilaian kinerja yang digunakan perusahaan untuk menilai kinerja karyawannya yaitu mengevaluasi hasil pekerjaan karyawan dengan sistem penilaian berdasarkan pencapaian produksi dan penjualan produk. Penilaian kinerja yang dilakukan dengan benar akan bermanfaat bagi karyawan. Sasaran yang menjadi objek dalam penilaian kinerja adalah kecakapan, kemampuan karyawan dalam melaksanakan suatu pekerjaan atau tugas yang dievaluasi dengan menggunakan tolak ukur tertentu secara objektif dan dilakukan secar berkala sehingga target produksi dan penjualan meningkat . Kinerja merupakan hasil kerja konkret yang dapat diamati dan dapat diukur. Kualitas karyawan yang semakin tinggi, diharapkan semakin tinggi kinerja perusahaan, sebaliknya, semakin rendah kualitas karyawan semakin rendah kinerja perusahaan. Seperti yang terlihat di Tabel berikut:

Tabel 1

Hasil Penjualan Produk

\begin{tabular}{|c|c|c|}
\hline No & Tahun & Produksi Produk $(\mathrm{Kg})$ \\
\hline 1 & 2014 & 137.904 .906 .34 \\
\hline 2 & 2015 & 133.169 .243 .25 \\
\hline 3 & 2016 & 128.987 .854 .98 \\
\hline
\end{tabular}

Sumber : Bagian PPIC PT KIC

Dari Tabel tersebut dapat dilihat bahwa penurunan penjualan produk pada tahun 20142016 yaitu dari tahun 2014 sebanyak $137.904 .906 .34 \mathrm{~kg}$ sampai $128.987 .854 .98 \mathrm{~kg}$. Penurunan produksi menunjukkan kinerja karyawan menurun seperti penelitian Windi et al (2014) menunjukkan bahwa produksi produk disebabkan kinerja karyawan, jika kinerja bagus maka produksi meningkat sedangkan kinerja tidak bagus maka produksi akan menurun. Hal ini menunjukkan bahwa kinerja karyawan PT KIC belum maksimal. Suatu perusahaan pasti akan senang mempunyai karyawan yang kinerja yang bagus terhadap perusahaan akan tetapi perusahaan akan kecewa mempunyai karyawan yang kinerja tidak bagus.

Dalam rangka mengwujudkan hal tersebut, perlu kiranya memperhatikan kualitas Sumber Daya Manusia (SDM) yang handal, terlatih, serta terampil dan peka terhadap tuntunan perusahaan. Hanya saja untuk menghasilkan sumberdaya manusia yang kinerja tinggi seorang karyawan tidak hanya perlu memiliki keterampilan, tetapi juga harus memiliki keinginan dan kegairahan untuk berprestasi tinggi. Oleh karena itu perlu adanya profesionalisme karyawan di PT KIC, bagaimana caranya membuat karyawan yang mempunyai potensial yang bagus baik dari segi kemampuan dan perilaku. Disinilah pentingnya pengelolaan sumberdaya manusia agar tercipta sumberdaya manusia yang unggul dan kreatif. Oleh sebab itu perlu dilakukan Pre Kuisoner terhadap 30 karyawan PT KIC untuk memgetahui faktor apa yang menyebabkan terjadinya penurunan kinerja, seperti yang terlihat pada Tabel berikut:

\section{Tabel 2}

\section{Hasil Rekapitulasi Kuisioner Pendahuluan}




\begin{tabular}{|c|c|c|c|c|}
\hline No & Pertanyaan & $\begin{array}{c}\text { Jumlah responden } \\
\text { menjawab Tidak Setuju } \\
\text { terbanyak }\end{array}$ & Item & Persen \\
\hline 1 & $\begin{array}{l}\text { Perusahaan selalu } \\
\text { memperhatikan disiplin } \\
\text { kerja saya }\end{array}$ & 17 orang & Disiplin & $56,67 \%$ \\
\hline 2 & $\begin{array}{l}\text { Saya mempunyai } \\
\text { motivasi yang tinggi } \\
\text { dalam bekerja untuk } \\
\text { kemajuan perusahaan }\end{array}$ & 18 orang & Motivasi & $60 \%$ \\
\hline 3 & $\begin{array}{l}\text { Dalam } 1 \text { tahun } \\
\text { perusahaan selalu } \\
\text { memberikan pelatihan } \\
\text { kepada saya }\end{array}$ & 20 orang & Pelatihan & $66,67 \%$ \\
\hline
\end{tabular}

Sumber :Karyawan PT KIC, 2017

Berdasarkan Tabel tersebut terdapat kuisoiner dengan 17 pernyataan secara umum yang diisi oleh 30 karyawan PT KIC. Hasil pertanyaan yang menunjukan hasil jawaban yang menjawab tidak setuju terbanyak, yaitu 56,67 \% orang tidak setuju dengan perusahaan selalu memperhatikan disiplin kerja, sebanyak $60 \%$ orang menjawab tidak setuju mempunyai motivasi yang tinggi dalam bekerja untuk kemajuan perusahaan, sebanyak 60,67\% orang tidak setuju Dalam 1 tahun perusahaan selalu memberikan pelatihan kepada saya. Hasil kuisoner tersebut menjadi alasan saya untuk membuat penelitian pengaruh disiplin, motivasi, dan pelatihan tehadap kinerja karyawan di PT KIC

Menurut penelitian Sukmasari H (2011) motivasi berpengaruh terhadap kinerja, menurut penelitian Hardjono T (2013) motivasi dan disiplin kerja berpengaruh terhadap kinerja kerja, menurut penelitian Windi et al (2014) motivasi, disiplin dan pelatihan kerja berpengaruh positif terhadap kinerja karyawan. PT. KIC masih terdapat karyawan yang tidak disiplin yaitu tidak masuk kerja tanpa keterangan yang meningkat dari pada bulan Januari dan Februari 2017 yaitu 10 dan 22 orang seperti yang terlihat Tabel tersebut :

\section{Tabel 3}

Data Kehadiran Karyawan PT KIC

Tahun 2016 dan 2017

\begin{tabular}{|c|c|c|c|c|c|c|}
\hline \multirow{2}{*}{ Bulan } & \multirow{3}{*}{ Tahun } & \multicolumn{5}{|c|}{ Keterangan Absensi } \\
\cline { 3 - 7 } & & Sakit & Izin & Alpha & Cuti & Terlambat \\
\hline Januari & 2016 & 69 & 40 & 0 & 637 & 0 \\
\hline
\end{tabular}




\begin{tabular}{|l|c|c|c|c|c|c|} 
Februari & 2016 & 80 & 13 & 0 & 637 & 0 \\
\hline Maret & 2016 & 93 & 6 & 2 & 344 & 11 \\
\hline April & 2016 & 121 & 8 & 2 & 384 & 2 \\
\hline Mei & 2016 & 138 & 18 & 0 & 279 & 4 \\
\hline Juni & 2016 & 194 & 7 & 2 & 326 & 5 \\
\hline July & 2016 & 165 & 14 & 1 & 363 & 4 \\
\hline Agustus & 2016 & 222 & 21 & 2 & 214 & 6 \\
\hline September & 2016 & 228 & 142 & 4 & 176 & 2 \\
\hline Oktober & 2016 & 182 & 83 & 32 & 196 & 8 \\
\hline November & 2016 & 142 & 27 & 6 & 166 & 1 \\
\hline Desember & 2016 & 160 & 482 & 2 & 129 & 6 \\
\hline Januari & 2017 & 53 & 61 & 10 & 789 & 6 \\
\hline Februari & 2017 & 76 & 34 & 22 & 417 & 7 \\
\hline \multicolumn{2}{|c|}{ Total } & 1923 & 522 & 58 & 5057 & 62 \\
\hline
\end{tabular}

Sumber : Bagian HRD PT KIC, 2016 dan 2017

Pada bulan Oktober 2016 menunjukkan alpha karyawan sebanyak 32 orang dari total karyawan yaitu 250 orang. Pada bulan Oktober cuti karyawan menjelang akhir tahun sudah habis yang berindikasi pada terjadi penurunan disiplin karyawan sedangkan pada bulan Januari dan Februari 2017 karyawan yang alpha yaitu 10 dan 22 seharusnya pada bulan tersebut karyawan baru mendapatkan cuti tahunan akan tetapi alpha di awal tahun tinggi dan meningkat dari bulan Januari ke Februari, hal ini menunjukkan bahwa tingkat disiplin karyawan menurun dibandingkan bulan Januari dan Februari 2017. Pada tabel 1.3 yaitu terdapat keterlambatan bulan maret tinggi yaitu 11 orang dan tahun 2016 pada bulan Januari dan Februari terjadi peningkatan pada Tahun 2017 hal ini menunjukkan terjadi penurunan disiplin karyawan.

Untuk memperkuat fakta tersebut dibuktikan dengan studi pendahuluan, peneliti melakukan pra-penelitian. Dengan melakukan observasi berupa penyebaran angket yang diajukan kepada karyawan PT KIC. Pernyataan yang diajukan dengan tujuan untuk mengetahui keadaan nyata motivasi kerja saat ini. Peneliti melakukan pra-penelitian tentang bagaimana gambaran motivasi kerja yang dimiliki karyawan PT KIC. Berikut Gambar 1.1 pada 30 responden hasil pra-penelitian tentang motivasi kerja PT KIC.

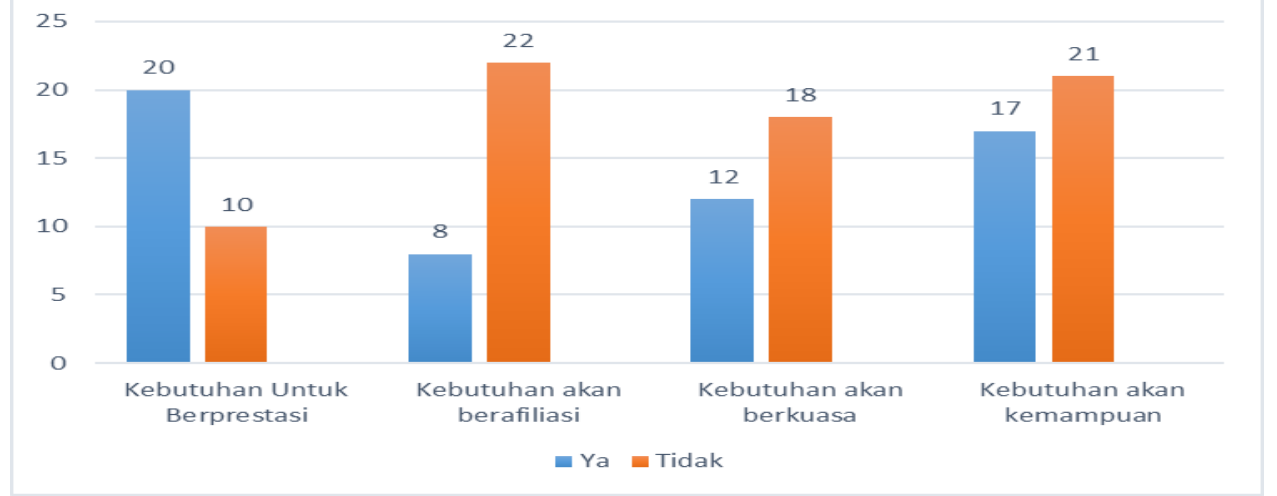

\section{Gambar 1}

57 IJurnal Manajemen \& Bisnis Kreatif 


\section{Hasil Pra Penelitian tentang Motivasi kerja \\ Sumber : Pra Penelitian (data diolah) 2017}

Dari indikator motivasi kerja di atas terdapat 4 indikator yang menunjukan motivasi kerja kurang baik yaitu kebutuhan akan berafililiasi, Kebutuhan akan berkuasa, dan kebutuhan akan kemampuan. Keempat indikator yang menunjukkan banyaknya jawaban tidak baik dari responden tersebut dapat mempengaruhi kinerja karyawan. Keberadaannya motivasi sangat penting dan diperlukan untuk mendukung kegiatan organisasi guna kelangsungan dan kemajuan perusahaan agar seluruh aktivitas yang dilaksanakan karyawan dapat berjalan dengan lancar sesuai aturan yang dibuat untuk mendukung optimal kinerja.

Faktor berikutnya yang diidentifikasikan berpengaruh pada kinerja adalah pelatihan. Pelatihan atau dengan istilah"Training" merupakan salah satu program perusahaan yang strategis dalam rangka mempertahankan dan memberikan motivasi kepada karyawan (Fuad 2004). Salah satu cara yang umum dilakukan perusahaan untuk meningkatkan kinerja adalah melalui pelatihan kerja. Setiap orang memiliki kemampuan masing-masing, akan tetapi kemampuan yang dimiliki belum tentu sesuai dengan spesifikasi yang dicari dan dibutuhkan oleh perusahaan, maka dari itu penting bagi perusahaan untuk melaksanakan pelatihan agar karyawan tahu apa yang seharusnya dilakukan dan bagaimana melakukannya. PT KAO Chemicals Indonesia. Rendahnya kinerja karyawan diduga dipengaruhi oleh pelatihan yang kurang baik. Hal tersebut dibuktikan dengan hasil studi pendahuluan pada Gambar dibawah ini pada 30 responden dengan hasil di bawah ini:

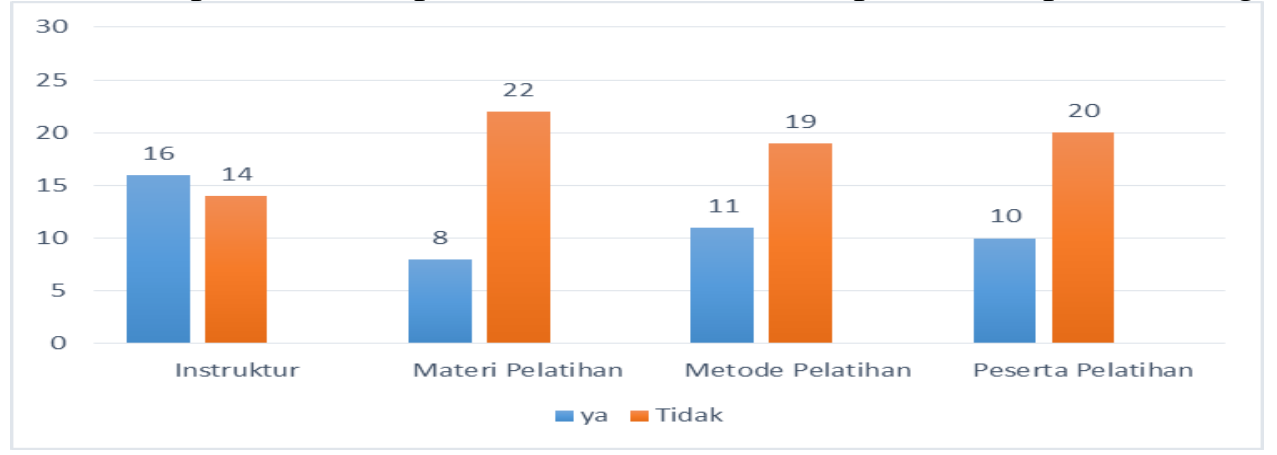

Gambar 2

Hasil Pra Penelitian tentang Pelatihan kerja

Sumber : Pra Penelitian (data diolah) 2017

Berdasarkan Gambar diatas kita dapat diketahui bahwa terdapat 3 indikator yang menunjukan pelatihan kurang baik yaitu materi pelatihan, metode pelatihan, dan peserta pelatihan. Hal ini menunjukkan bahwa pelatihan yang dilakukan oleh perusahaan kurang efektif yang berdampak pada kinerja kerja karyawan seperti penelitian. Pernyataan diatas sejalan dengan hasil penelitian Windi et al (2014) menyatakan bahwa pelatihan mempunyai pengaruh positif terhadap kinerja kerja.

\section{B. TINJAUAN PUSTAKA}

\subsection{Disiplin Kerja}


Disiplin adalah prosedur yang mengoreksi atau menghukum bawahan karena melanggar peraturan atau prosedur. Disiplin merupakan bentuk pengendalian diri karyawan dan pelaksanaan yang teratur dan menunjukan tingkat kesungguhan tim kerja di dalam organisasi (Henry Simamora, 2006) Menurut Moenir (2002), disiplin adalah suatu bentuk ketaatan terhadap aturan, baik tertulis maupun tidak tertulis yang telah ditetapkan. Disiplin harus ditumbuh kembangkan agar tumbuh pula ketertiban dan efisiensi. Sedangkan menurut Mangkunegara (2011), disiplin haruslah dimiliki oleh setiap karyawan dan harus terus ditingkatkan. Salah satu syarat agar dapat ditumbuhkan disiplin dalam lingkungan kerja ialah, adanya pembagian pekerjaan yang tuntas sampai kepada pegawai atau petugas yang paling bawah, sehingga setiap orang tahu dengan sadar apa tugasnya, bagaimana melakukannya.

\subsection{Motivasi Kerja}

Motivasi adalah hal yang menyebabkan, menyalurkan, dan mendukung perilaku manusia, supaya mau bekerja giat dan antusias mencapai hasil yang optimal. Motivasi semakin penting karena manajer membagikan pekerjaan pada bawahannya untuk dikerjakan dengan baik dan terintegrasi kepada tujuan yang ditentukan (Hasibuan, 2003). Setiap kegiatan yang dilakukan oleh seseorang didorong oleh suatu kekuatan dari dalam diri seseorang, kekuatan pendorong inilah yang disebut motivasi (Fuad Maseeud, 2002). Menurut Robbins (2012) motivasi sebagai proses yang menjelaskan intensitas, arah, dan ketekunan seorang individu untuk mencapai tujuannya. Suasana batin atau psikologis seorang pekerja sebagai individu dalam masyarakat organisasi atau perusahaan yang menjadi lingkungan kerjanya, sangat besar pengaruhnya pada pelaksanaan pekerjaannya. Suasana batin itu terlihat dalam semangat atau gairah kerja yang menghasilkan kegiatan kerja sebagai kontribusi bagi pencapaian tujuan bisnis perusahaan (Hadari Nawawi, 2005).

\subsection{Pelatihan Kerja}

Menurut Hasibuan (2013:243), tujuan pelatihan dan pengembangan karyawan adalah untuk memperbaiki efektivitas kerja karyawan dalam mencapai hasil-hasil kerja yang telah di tetapkan. Peningkatan efektivitas kerja dapat dilakukan dengan latihan (Training) dan/atau pengembangan (Development). Latihan dimaksudkan untuk memperbaiki penguasaan keterampilan-keterampilan dan teknik-teknik pelaksanaan pekerjaan tertentu, terperinci dan rutin. Pengembangan mempunyai ruang lingkup lebih luas dalam pengembangan dan peningkatan kemampuan, sikap dan sifat-sifat kepribadian.Karyawan-karyawan baru biasanya telah mempunyai pendidikan dan latihan dasar yang dibutuhkan. Mereka adalah produk dari suatu tingkat kemampuan dan kecakapan tertentu.

\subsection{Kinerja Kerja}

Kinerja yang disampaikan Herdiyanto (2003) yang mengadopsi arti kinerja dari Gibson (2007). Menurut Herdiyanto, kinerja adalah hasil dari suatu perilaku seseorang atau kelompok yang terkait dengan cara kerjanya. Pada setiap orang yang bekerja atau dalam suatu kelompok kerja, kinerja selalu diharapkan bisa senantiasa baik kualitas dan kuantitasnya. Kinerja adalah hasil kerja secara kualitas dan kuantitas yang dicapai oleh seorang pegawai dalam melaksanakan tugasnya sesuai dengan tanggung jawab yang diberikan kepadanya (Mangkunegara, 2004). 


\section{METODE PENELITIAN DAN ANALISIS DATA}

Metode penelitian pada dasarnya merupakan cara ilmiah untuk mendapatkan data dengan tujuan dan keegunaan tertentu. Cara ilmiah kegiatan penelitian itu didasarkan pada ciri-ciri keilmuan, yaitu rasional, empiris, dan sistematis (Sugiyono 2012:2). Dalam penelitian ini menggunakan metode penelitian deskriptif dan verifikatif.Menurut Sugiyono (2012:35), penelitian deskriptif adalah penelitian yang dilakukan untuk mengetahui nilai variabel mandiri, baik satu variabel atau lebih (independent) tanpa membuat perbandingan atau menghubungkan dengan variabel yang lain. Penelitian verifikatif menurut Sugiyono (2012:3) bahwa metode penelitian kuantitatif yang digunakan untuk penelitian populasi atau sampel tertentu, dan analisis data bersifat statistik dengan tujuan untuk menguji hipotesis yang telah ditetapkan.Tujuan dari penelitian deskriptif adalah untuk memperoleh gambaran secara sistematis mengenai Disiplin Kerja, motivasi kerja, Pelatihan sebagai variabel bebas dan Kinerja sebagai variabel terikat, sedangkan secara verifikatif bertujuan untuk menguji hipotesis dengan perhitungan statistik.

\section{HASIL PENELITIAN}

Responden dalam penelitian ini adalah PT KICyang berjumlah 154 orang, dengan karakteristik sebagai berikut :

1. Jumlah Responden Berdasarkan Jenis Kelamin.

Tabel 5

Jumlah Responden Berdasarkan Jenis Kelamin

\begin{tabular}{|c|c|c|c|}
\hline No & Usia & Jumlah (orang) & Persentase (\%) \\
\hline 1 & Laki-laki & 149 & 96,8 \\
\hline 2 & Perempuan & 5 & 3,2 \\
\hline & Total & 154 & 100 \\
\hline
\end{tabular}

Sumber : Hasil pengolahan data, 2017

2. Jumlah Responden Berdasarkan Usia

Tabel 6

Jumlah Responden Berdasarkan Usia

\begin{tabular}{|c|c|c|c|}
\hline & & & \\
No & Jenis Kelamin & Jumlah (orang) & Persentase (\%) \\
\hline 1 & Dibawah 26 Tahun & 41 & 26,7 \\
\hline 2 & $26-30$ Tahun & 59 & 38,3 \\
\hline 3 & $31-35$ Tahun & 33 & 21,4 \\
\hline 4 & Diatas 36 Tahun & 21 & 13,6 \\
\hline
\end{tabular}




\begin{tabular}{|c|c|c|}
\hline Total & 154 & 100 \\
\hline
\end{tabular}

Sumber : Hasil pengolahan data, 2017

\subsection{Uji Validitas}

dibawah ini adalah hasil pengujian tingkat validitas dari setiap item kuisioner dan dikelompokan ke dalam tiap variabel yaitu :

Tabel 7

Hasil Uji Validitas Variabel Disiplin Kerja

\begin{tabular}{|l|c|c|c|c|}
\hline \multicolumn{1}{|c|}{ Dimensi } & $\begin{array}{c}\text { No } \\
\text { Pernyataan }\end{array}$ & r Hitung & r Kritis & Kriteria \\
\hline Tepat Waktu & 1 & 0.581 & 0.3 & Valid \\
\hline Rapat Pagi & 2 & 0.609 & 0.3 & Valid \\
\hline Jam Kerja & 3 & 0.385 & 0.3 & Valid \\
\hline Sesuai dengan aturan & 4 & 0.337 & 0.3 & Valid \\
\hline Prosedur Kerja & 5 & 0.558 & 0.3 & Valid \\
\hline Tanggungjawab kerja & 6 & 0.341 & 0.3 & Valid \\
\hline Keselamatan kerja & 7 & 0.443 & 0.3 & Valid \\
\hline Bersikap Hati-hati & 8 & 0.523 & 0.3 & Valid \\
\hline Penuh Perhitungan & 9 & 0.366 & 0.3 & Valid \\
\hline Efeketif dan efisien & 10 & 0.407 & 0.3 & Valid \\
\hline Etika kerja & 11 & 0.568 & 0.3 & Valid \\
\hline $\begin{array}{l}\text { Menghormati atasan dan } \\
\text { rekan kerja }\end{array}$ & 12 & 0.523 & 0.3 & Valid \\
\hline
\end{tabular}

Sumber: Hasil Pengolahan Data, 2017

Berdasarkan tabel di atas diketahui bahwa 12 butir pertanyaan dari 12 indikator Disiplin Kerja dinyatakan valid $(r \geq 0.3)$. Untuk uji validitas variabel Motivasi terlihat dalam Tabel dibawah ini :

Tabel 8

Hasil Uji Validitas Variabel Motivasi Kerja

\begin{tabular}{|l|c|c|c|c|}
\hline \multicolumn{1}{|c|}{ Dimensi } & $\begin{array}{c}\text { No } \\
\text { Pernyataan }\end{array}$ & $\begin{array}{c}\mathbf{r} \\
\text { Hitung }\end{array}$ & $\begin{array}{c}\mathbf{r} \\
\text { Kriti } \\
\mathbf{S}\end{array}$ & Kriteria \\
\hline Tanggung jawab & 1 & 0.326 & 0.3 & Valid \\
\hline Berani mengambil Resiko & 2 & 0.564 & 0.3 & Valid \\
\hline Tujuan yang realistis & 3 & 0.482 & 0.3 & Valid \\
\hline Memiliki rencana kerja & 4 & 0.451 & 0.3 & Valid \\
\hline Sifat sosial & 5 & 0.515 & 0.3 & Valid \\
\hline
\end{tabular}




\begin{tabular}{|l|c|c|c|c|}
\hline Interaksi & 6 & 0.499 & 0.3 & Valid \\
\hline Patisipasi kelompok & 7 & 0.476 & 0.3 & Valid \\
\hline Menanamkan pengaruh & 8 & 0.607 & 0.3 & Valid \\
\hline Empati & 9 & 0.470 & 0.3 & Valid \\
\hline Kelebihan atau kemampuan & 10 & 0.501 & 0.3 & Valid \\
\hline $\begin{array}{l}\text { Melaksanakan Tugas tepat } \\
\text { waktu }\end{array}$ & 11 & 0.573 & 0.3 & Valid \\
\hline Keterampilan dan Keahlian & 12 & 0.470 & 0.3 & Valid \\
\hline Perilaku yang baik & 13 & 0.410 & 0.3 & Valid \\
\hline Variasi Pekerjaan & 14 & 0.420 & 0.3 & Valid \\
\hline
\end{tabular}

Sumber : Hasil Pengolahan Data, 2017

Dari hasil uji validitas variabel Motivasi sebanyak 14 item kuisioner dinyatakan valid karena memiliki nilai $r$ hitung $\geq 0.3$. Uji Validitas variable Pelatihan Kerja terlihat pada Tabel dibawah ini :

Tabel 9

Hasil Uji Validitas Variabel Pelatihan Kerja

\begin{tabular}{|l|c|c|c|c|}
\hline \multicolumn{1}{|c|}{ Dimensi } & $\begin{array}{c}\text { No } \\
\text { Pernyataan }\end{array}$ & r Hitung & r Kritis & Kriteria \\
\hline Penyampaian materi & 1 & 0.428 & 0.3 & Valid \\
\hline Penguasaan materi & 2 & 0.355 & 0.3 & Valid \\
\hline Sesuai kebutuhan & 3 & 0.431 & 0.3 & Valid \\
\hline Sesuai pekerjaan & 4 & 0.561 & 0.3 & Valid \\
\hline $\begin{array}{l}\text { Sesuai tujuan } \\
\text { perusahaan }\end{array}$ & 5 & 0.498 & 0.3 & Valid \\
\hline $\begin{array}{l}\text { Membantu } \\
\text { menyelesaikan } \\
\text { pekerjaan }\end{array}$ & 6 & 0.564 & 0.3 & Valid \\
\hline Metode belajar & 7 & 0.571 & 0.3 & Valid \\
\hline Metode praktik & 8 & 0.394 & 0.3 & Valid \\
\hline $\begin{array}{l}\text { Kriteria tertentu yang } \\
\text { dimiliki peserta }\end{array}$ & 9 & 0.475 & 0.3 & Valid \\
\hline Kesesuaian seleksi & 10 & 0.515 & 0.3 & Valid \\
\hline Kemampuan & 11 & 0.540 & 0.3 & Valid \\
\hline Prestasi kerja & 12 & 0.414 & 0.3 & Valid \\
\hline
\end{tabular}

\section{Sumber : Hasil Pengolahan Data, 2017}

Dari hasil uji validitas variabel Motivasi sebanyak 12 item kuisioner dinyatakan valid karena memiliki nilai $r$ hitung $\geq 0.3$. Untuk uji validitas variabel Kinerja terlihat dalam Tabel dibawah ini : 
Tabel 10

Hasil Uji Validitas Variabel Kinerja

\begin{tabular}{|l|c|c|c|c|}
\hline \multicolumn{1}{|c|}{ Dimensi } & $\begin{array}{c}\text { No } \\
\text { Pernyataan }\end{array}$ & r Hitung & r Kritis & Kriteria \\
\hline Pengetahuan & 1 & 0.462 & 0.3 & Valid \\
\hline Keahlian & 2 & 0.591 & 0.3 & Valid \\
\hline Sikap & 3 & 0.414 & 0.3 & Valid \\
\hline Tujuan kerja & 4 & 0.526 & 0.3 & Valid \\
\hline Prestasi kerja & 5 & 0.519 & 0.3 & Valid \\
\hline Inisiatif & 6 & 0.482 & 0.3 & Valid \\
\hline Keinginan maju & 7 & 0.631 & 0.3 & Valid \\
\hline Kepercayaan & 8 & 0.564 & 0.3 & Valid \\
\hline Kreatifitas & 9 & 0.578 & 0.3 & Valid \\
\hline Kemampuan verbal & 10 & 0.615 & 0.3 & Valid \\
\hline Disiplin Kerja & 11 & 0.427 & 0.3 & Valid \\
\hline Kuantitas kerja & 12 & 0.572 & 0.3 & Valid \\
\hline Kualitas kerja & 13 & 0.487 & 0.3 & Valid \\
\hline Keterampilan kerja & 14 & 0.427 & 0.3 & Valid \\
\hline Integritas & 15 & 0.308 & 0.3 & Valid \\
\hline
\end{tabular}

Sumber : Hasil Pengolahan Data, 2017

Dari hasil uji validitas variabel Kinerja Karyawan sebanyak 15 item kuisioner dinyatakan valid karena memiliki nilai $r$ hitung $\geq 0.3$.

\subsection{Uji Reliabilitas}

Hasil Pengolahan data dengan menggunakan Software SPSS 22.0, diperoleh hasil pengujian dari seluruh variabel seperti terlihat dalam tabel sebagai berikut :

Tabel 11

Hasil Uji Reliabilitas

\begin{tabular}{|c|l|c|c|c|}
\hline No & \multicolumn{1}{|c|}{ Variabel } & r Hitung & r Kritis & Keterangan \\
\hline 1 & Disiplin Kerja $\left(\mathrm{X}_{1}\right)$ & 0.816 & 0.70 & $\begin{array}{c}\text { Sangat } \\
\text { Reliabel }\end{array}$ \\
\hline 2 & Motivasi Kerja $\left(\mathrm{X}_{2}\right)$ & 0.844 & 0.70 & $\begin{array}{c}\text { Sangat } \\
\text { Reliabel }\end{array}$ \\
\hline 3 & Pelatihan Kerja $\left(\mathrm{X}_{3}\right)$ & 0.825 & 0.70 & $\begin{array}{c}\text { Sangat } \\
\text { Reliabel }\end{array}$ \\
\hline 3 & Kinerja $(\mathrm{Y})$ & 0.863 & 0.70 & $\begin{array}{c}\text { Sangat } \\
\text { Reliabel }\end{array}$ \\
\hline
\end{tabular}

Sumber : Hasil pengolahan data, 2017 
Tabel 4.7 memperlihatkan bahwa hasil uji reliabilitas diketahui bahwa utuk setiap variabel, (Nilai alpha cronbach 0.81 s.d. 1.00, berarti sangat reliable). Sehingga Disiplin Kerja, Motivasi, pelatihan kerja dan Kinerja dinyatakan Sangat Reliabel.

Tabel 12

Hasil Uji Normalitas

\begin{tabular}{|l|c|c|c|}
\hline \multirow{2}{*}{ Variabel } & \multicolumn{2}{|c|}{ Kolmogrov - Smirnov } & \multirow{2}{*}{ Keterangan } \\
\cline { 2 - 3 } & r Hitung & r Kritis & $\begin{array}{c}\text { Distribusi } \\
\text { Normal }\end{array}$ \\
\hline Disiplin Kerja $\left(\mathrm{X}_{1}\right)$ & 0.055 & 0.05 & $\begin{array}{c}\text { Distribusi } \\
\text { Normal }\end{array}$ \\
\hline Motivasi $\left(\mathrm{X}_{2}\right)$ & 0.074 & 0.05 & $\begin{array}{c}\text { Distribusi } \\
\text { Normal }\end{array}$ \\
\hline Pelatihan $\left(\mathrm{X}_{3}\right)$ & 0.065 & 0.05 & $\begin{array}{c}\text { Distribusi } \\
\text { Normal }\end{array}$ \\
\hline Kinerja (Y) & 0.080 & 0.05 & \\
\hline
\end{tabular}

Sumber: Hasil pengolahan data, 2017

Pada tabel 4.8 diatas menunjukan bahwa semua variabel mengikuti sebaran data normal karena nilai signifikan $\alpha$ hitung semua variabel lebih dai 0.05 . Variabel Disiplin Kerja sebesar 0.055, Motivasi 0.074, Pelatihan sebesar 0.065 dan Kinerja 0.080 , maka semua variabel dinyatakan mengikuti sebaran data normal.

\section{E. PEMBAHASAN DAN HASIL PENELITIAN}

Pengaruh Disiplin Kerja $\left(X_{1}\right)$, Motivasi $\left(X_{2}\right)$ dan Pelatihan $\left(X_{3}\right)$ terhadap Kinerja Karyawan (Y)

Pengaruh Disiplin Kerja $\left(\mathrm{X}_{1}\right)$, Motivasi $\left(\mathrm{X}_{2}\right)$ dan Pelatihan $\left(\mathrm{X}_{3}\right)$ terhadap Kinerja Karyawan $(\mathrm{Y})$ dapat dilihat pada tabel 4.68 berikut ini:

Tabel 13

Pengaruh Disiplin Kerja $\left(\mathbf{X}_{1}\right)$, Motivasi Kerja $\left(\mathbf{X}_{2}\right)$ dan Pelatihan Kerja ( $\left.\mathbf{X}_{3}\right)$ terhadap Kinerja Karyawan (Y)

\begin{tabular}{|l|l|l|l|l|l|l|}
\hline \multirow{2}{*}{ Variabel } & \multirow{2}{*}{$\begin{array}{c}\text { Koefisien } \\
\text { Jalur }\end{array}$} & \multirow{2}{*}{$\begin{array}{l}\text { Pengaruh } \\
\text { Langsung }\end{array}$} & \multicolumn{3}{c|}{$\begin{array}{c}\text { Pengaruh Tidak } \\
\text { Langsung }\end{array}$} & \multirow{2}{*}{$\begin{array}{c}\text { Subtotal } \\
\text { Pengaruh }\end{array}$} \\
\cline { 4 - 7 } & & & X1 & X2 & X3 & \\
\hline Disiplin Kerja & 0,339 & 0,115 & 0,144 & ------ & ------- & 0,259 \\
\hline Motivasi & 0,291 & 0,085 & ------ & 0,146 & ------- & 0,231 \\
\hline Pelatihan & 0,350 & 0,123 & ------ & ----- & 0,148 & 0,271 \\
\hline \multicolumn{3}{|c|}{ Total Pengaruh } & & 0,761 \\
\hline
\end{tabular}


Sumber: Hasil Pengolahan Data, 2017

Pada tabel 4.68 di atas menunjakan bahwa total pengaruh yang disebabkan Disiplin Kerja $\left(\mathrm{X}_{1}\right)$, Motivasi $\left(\mathrm{X}_{2}\right)$ dan Pelatihan $\left(\mathrm{X}_{3}\right)$ terhadap Kinerja Karyawan $(\mathrm{Y})$ yaitu sebesar 0,761 atau $76,1 \%$ adapun pengaruh variabel lain diluar model adalah sebesar 0,239 atau 23,9\%

\section{Tabel 14}

Koefisien Determinasi

Model Summary

\begin{tabular}{|l|c|r|r|r|}
\hline $\begin{array}{l}\text { Mod } \\
\text { el }\end{array}$ & $\mathrm{R}$ & $\begin{array}{c}\mathrm{R} \\
\text { Square }\end{array}$ & $\begin{array}{c}\text { Adjusted } \\
\text { R Square }\end{array}$ & $\begin{array}{c}\text { Std. Error } \\
\text { of the } \\
\text { Estimate }\end{array}$ \\
\hline 1 & $.872^{\mathrm{a}}$ & .760 & .755 & 3.99880 \\
\hline
\end{tabular}

Sumber: Hasil Pengolahan data 2017

Berdasarkan tabel 4.69 di atas menunjukan bahwa koefisien determinasi $\left(\mathrm{R}^{2}\right)$ sebesar 0,760 berarti 76\% variabel Kinerja Karyawan (Y) bisa diterangkan oleh variabel Disiplin Kerja ( $\left.\mathrm{X}_{1}\right)$, Motivasi $\left(\mathrm{X}_{2}\right)$ dan Pelatihan $\left(\mathrm{X}_{3}\right)$, atau dapat diartikan bahwa Disiplin Kerja $\left(\mathrm{X}_{1}\right)$, Motivasi $\left(\mathrm{X}_{2}\right)$ dan Pelatihan $\left(\mathrm{X}_{3}\right)$ memiliki konstribusi terhadap Kinerja Karyawan (Y) sebesar 76\% sedangkan sisanya 24\% Merupakan kontribusi variabel lain ( $(\varepsilon)$ yang tidak diteliti.

\subsection{Hipotesis Pengaruh Variable Secara Simultan}

Pengaruh Disiplin Kerja $\left(\mathrm{X}_{1}\right)$, Motivasi $\left(\mathrm{X}_{2}\right)$ dan Pelatihan $\left(\mathrm{X}_{3}\right)$ secara simultan (keseluruhan) terhadap Kinerja Karyawan (Y) dapat diketahui melalui pengujian statistik dengan menggunakan hipotesis sebagai berikut:

Hipotesis statistik:

$H_{0}: \rho y x_{1}=\rho y x_{2}=\rho y x_{3}=0$ (tidak ada pengaruh)

$H_{1}: \rho y x_{1} \neq \rho y x_{2} \neq \rho y x_{3} \neq 0$ (ada pengaruh)

Hipotesis bentuk kalimat:

$H_{0}$ : Disiplin Kerja, motivasi kerja dan Pelatihan secara simultan tidak berpengaruh terhadap kinerja

$H_{1}$ ¿Disiplin Kerja, motivasi kerja dan Pelatihan secara simultan berpengaruh terhadap kinerja.

Kriteria Uji : Tolak $H_{o}$ jika Sig. $<\alpha$ atau $t_{\text {hitung }}>f_{\text {tabel }}$

Untuk pengaruh Disiplin Kerja, Motivasi dan Pelatihan secara simultan terhadap Kinerja Karyawan dengan tingkat signifikan $(\alpha)=5 \%$, degree of freedom $(\mathrm{df})=(\mathrm{n}-2)=154-2=152$, diperoleh $\mathrm{f}_{\text {tabel }}=3,09$. Sedangkan $\mathrm{f}_{\text {hitung }}$ dapat dilihat pada tabel di bawah ini :

\section{Tabel 15}

Hasil Perhitungan Nilai F

ANOVA ${ }^{a}$

\begin{tabular}{|l|l|l|l|l|l|}
\hline & $\begin{array}{l}\text { Sum of } \\
\text { Squares }\end{array}$ & df & Mean Square & F & Sig. \\
\hline
\end{tabular}

65 |Jurnal Manajemen \& Bisnis Kreatif 


\begin{tabular}{|ll|r|r|r|r|r|}
\hline 1 & Regression & 7607.490 & 3 & 2535.830 & 158.585 & $.000^{\mathrm{b}}$ \\
& Residual & 2398.556 & 150 & 15.990 & & \\
Total & 10006.046 & 153 & & & \\
\hline
\end{tabular}

a. Dependent Variable: KINERJA

b. Predictors: (Constant), PELATIHAN, DISIPLIN KERJA, MOTIVASI

n Data, 2017

Berdasarkan tabel 4.73 di atas, menunjukan bahwa $f_{\text {hitung }}=158.585$ dan sig. 0,000. Pengaruh Disiplin Kerja (X1), Motivasi (X2) dan Pelatihan ( $\left.\mathrm{X}_{3}\right)$ secara simultan terhadap Kinerja Karyawan (Y) diperlihatkan pada tabel di bawah ini :

Tabel 16

Pengaruh Simultan Disiplin Kerja $\left(\mathbf{X}_{1}\right)$, Motivasi $\left(\mathbf{X}_{2}\right)$

Dan Pelatihan $\left(\mathrm{X}_{3}\right)$ terhadap Kinerja Karyawan (Y)

\begin{tabular}{|c|c|c|c|c|c|}
\hline Structural & Sig. & $\boldsymbol{\alpha}$ & $\mathbf{f}_{\text {hitung }}$ & $\mathbf{f}_{\text {tabel }}$ & Kesimpulan \\
\hline $\mathrm{Pyx}_{1}, \mathrm{X}_{2, \mathrm{X} 3}$ & 0,000 & 0,05 & 158,585 & 3,06 & $\mathrm{H}_{\mathrm{o}}$ ditolak \\
\hline
\end{tabular}

Sumber : Hasil Pengolahan Data, 2017

Tabel 4.74 diatas menunjukan bahwa nilai sig. $(0,000)<\alpha(0,05)$ dan $f_{\text {hitung }}(158,585)$ $>f_{\text {tabel }}(3,06)$ maka $\mathrm{H}_{\mathrm{o}}$ ditolak. Dengan demikian dapat disimpulkan bahwa Disiplin Kerja, Motivasi dan Pelatihan secara simultan berpengaruh positif dan signifikan terhadap Kinerja Karyawan.

\section{F. Simpulan}

Berdasarkan hasil penelitian, pengumpulan data dan pembahasan yang dilakukan peneliti pada PT KIC maka dapat di ambil kesimpulan sebagai berikut :

1. Disiplin Kerja pada PT KIC sudah sesuai aturan perusahaan, karena Indikator yang diteliti dengan dari 12 indikator sebesar 6.878 dan nilai rata-rata yaitu 573,2, yang pada rentang skala 523,6-646,8 berada pada kriteria setuju. Hal ini menunjukan persepsi karyawan PT KAO Indonesia Chemcals menyatakan setuju terhadap Disiplin kerja sudah baik.

2. Motivasi pada PT KIC yang diberikan kepada karyawan sudah baik, karena indikator yang diteliti dengan total skor dari 14 indikator sebesar 7.847 dan nilai rata-rata yaitu 560,5 yang berada pada rentang skala 523,6-646,8. Hal ini menunjukan persepsi karyawan PT. KIC menyatakan setuju terhadap motivasi yang diberikan oleh perusahaan sudah baik.

3. Pelatihan pada PT KIC sudah berjalan dengan baik karena indikator yang diteliti dinyatakan setuju oleh responden dengan total skor 6.596 dengan rata-rata 549,7, yang berada pada rentang skala 523,6-646,8. Hal ini menunjukan persepsi karyawan PT. KIC menyatakan setuju terhadap pelatihan yang diadakan oleh perusahaan sudah baik. 
4. Kinerja Karyawan pada PT KIC memiliki kinerja yang baik, karena indikator yang diteliti dengan total skor sebesar 8.739 dan nilai rata-rata yaitu 582,6 yang berada pada rentang skala 523,6-646,8 berada pada kriteria setuju. Hal ini menunjukan persepsi karyawan PT KIC menyatakan setuju terhadap kinerja karyawan sudah baik.

5. Disiplin, Motivasi, dan Pelatihan kerja secara parsial mempunyai pengaruh yang positif dan signifikan terhadap Kinerja.

a. Koefisien jalur variabel Disiplin secara parsial terhadap Kinerja adalah sebesar 0,339 dan besar total pengaruhnya (langsung + tidak langsung) sebesar 0,259 atau 25,9\%.

b. Koefisien jalur variabel Motivasi secara parsial terhadap Kinerja adalah sebesar 0,350. dan besar total pengaruhnya (langsung + tidak langsung) sebesar 0,231 atau 23,1\%.

c. Koefisien jalur variabel Pelatihan secara parsial terhadap Kinerja adalah sebesar 0,291. dan besar total pengaruhnya (langsung + tidak langsung) sebesar 0,271 atau 27,1\%.

Karena 0,350 lebih besar dari 0,339 dan 0,291 maka dapat dinyatakan bahwa variabel Pelatihan lebih banyak memberikan pengaruh terhadap Kinerja dibandingkan variabel Disiplin dan Motivasi. Hal ini disebabkan karena responden mempunyai pandangan Pelatihan sangat mempengaruhi Kinerja jika Pelatihan di nilai tidak bagus oleh para karyawan, maka karyawan tidak akan memiliki kinerja yang baik.

6. Disiplin Kerja, Motivasi dan Pelatihan secara simultan berpengaruh positif dan signifikan terhadap Kinerja Karyawan. Disiplin Kerja, Motivasi dan Pelatihan terhadap Kinerja Karyawan yaitu sebesar 0,761 atau $76,1 \%$ adapun pengaruh variabel lain diluar model adalah sebesar 0,239 atau $23,9 \%$.

\section{G. Saran}

Berdasarkan dari hasil penelitian yang dilakukan dan dalam kesempatan ini penulis akan sedikit memberikan beberapa saran, diharapkan dapat menjadi bahan masukan dan bahan pertimbangan bagi PT KIC yang sifatnya untuk kemajuan perusahaan tersebut:

1. Diharapkan perusahaan terus menjaga serta terus meningkatkan Disiplin Kerja karyawan agar lebih baik lagi. Berdasarkan hasil tanggapan responden terdapat 3 indikator yang mengatakan cukup setuju sedangkan sisanya 9 mengatakan sangat setuju dan setuju.

2. Diharapkan perusahaan terus meningkatkan motivasi kerja karyawan karena dengan motivasi yang tinggi maka tujuan organisasi dapat tercapai. Berdasarkan hasil tanggapan responden terdapat 5 indikator yang mengatakan cukup setuju sedangkan sisanya 9 mengatakan sangat setuju dan setuju.

3. Diharapkan perusahaan dapat terus mengadakan Pelatihan kerja karyawan agar seluruh karyawan dapat meningkatkan kemampuannya. Berdasarkan hasil tanggapan responden terdapat 5 indikator yang mengatakan cukup setuju sedangkan sisanya 7 mengatakan setuju.

4. Diharapkan perusahaan dapat meningkatkan Kinerja Karyawan karena dengan kinerja yang baik tentunya akan mampu meningkatkan hasil produksi yang ditetapkan. Berdasarkan hasil tanggapan responden terdapat 1 indikator yang mengatakan cukup setuju sedangkan sisanya 14 mengatakan sangat setuju dan setuju.

5. Dari penelitian yang telah dilakukan terhadap pengaruh parsial antara Disiplin terhadap Kinerja sebesar 18,8\% dan terdapat pengaruh parsial antara Motivasi terhadap Kinerja 15,6\% kemudian pengaruh parsial Komunikasi Terhadap Kinerja 19,8\%. Karena 15,6\% lebih kecil dari 29,4\% maka dapat dinyatakan Motivasi PT KIC Kurang memberikan 
konstribusi terhadap kinerja sehingga nilainya masih rendah. Responden mengharapkan PT KIC agar lebih meningkatkan Motivasinya. Sehingga PT KIC dapat bertahan dan lebih meningkatkan kinerja para karyawannya.

6. Diharapkan untuk penelitian lebih lanjut meneliti variable lain yang mempengaruhi kinerja tetapi tidak diteliti seperti Kompensasi dan kepuasan kerja, sehingga diharapkan kinerja karyawan semakin meningkat dan sebagai pertimbangan bagi organisasi dalam menentukan kebijakan yang akan ditetapkan.

\section{H. DAFTAR PUSTAKA}

Agus Setiawan. 2013. Pengaruh Disiplin Kerja Dan Motivasi Terhadap Kinerja Karyawan Pada

Rumah Sakit Umum Daerah Kanjuruhan Malang. Jurnal Ilmiah Manajemen. Surabaya: UNS.

Achmad S. Ruky. 2010., Sistem Manajemen Kinerja (Performance Management System), Panduan Praktis Untuk Merancang dan Meraih Kinerja Prima, PT. Gramedia Pustaka Utama, Jakarta,

Ambarwati,dkk. 2012. Analisis Pengaruh Motivasi Kerja, Pendidikan, dan Pelatihan Terhadap Kinerja Pegawai Badan Kepegawaian Daerah Kabupaen Tulungagung. Jurnal OTONOMI. Vol.12, No.1, Januari 2012.

Amri, Kahirul. 2015. Pengaruh Motivasi terhadap Produtivitas Kerja Karyawan pada PT. Semen Padang, Tbk. Padang: Universitas Putra Indonesia

Amran. 2009. Pengaruh Disiplin Kerja Terhadap Kinerja Pegawai Kantor Departemen Sosial Kabupaten Gorontalo. Jurnal Ilmiah Manajemen. Gorontalo, Vol 4, No 2.

Arep, Ishak \& Tanjung, Hendri. 2002. Manajemen Motivasi. Jakarta: Grasindo.

Arikunto, Suharsimi. 2002. Prosedur Penelitian. Jakarta: Rhineka Cipta.

Arsyenda Y. 2013. Pengaruh Motivasi Kerja dan Disiplin kerja Terhadap Kinerja PNS (Studi Kasus : BAPPEDA Kota Malang). [Jurnal Ilmiah] Universitas Brawijaya.

Azhar. 2001. Pokok-Pokok Manajemen: Pengetahuan Praktis Bagi Pimpinan dan Eksekutif. Jakarta : Rineka Cipta.

Buku Pedoman Penyusunan Tugas Akhir Mahasiswa S2 Manajemen. 2015. Fakultas Ekonomi Universitas Singaperbangsa Karawang

Buku Pedoman Penyusunan Tugas Akhir Mahasiswa S2 Manajemen. 2015. Fakultas Ekonomi Universitas Singaperbangsa Karawang

Badudu, Zain.2013.Pengaruh Lingkungan Kerja Terhadap Kinerja Kerja Pegawai BAPPEDA Malikussaleh Industrial Engineering Journal Vol.2 No.1 18-23ISSN : 2302 934X 
Bestari, Ridho. 2011. Pengaruh Kompensasi dan Disiplin Kerja terhadap Produktivitas Kerja Karyawan Bagian Produksi PT. Berkat Sejahtera Abadi. Jurnal Media Mahardhika Vol 10 No. 2 Januari 2011

Campbell D.T., \& Fiske, D.W. 1959. Convergent And Discriminant Validation By The Multitrait-Multimethod Matrix. Psychological Bulletin. 56, 81-105.

Emily, B., 2000, The Company They Keep, Volume 22, United States

Fuad Mas`ud. 2004. Survai Diagnosis Organisasional, Konsep \& Aplikasi.

Semarang: Badan Penerbit Universitas Diponegoro

Gibson, Ivancevich, 2006. Organisasi: Proses Struktur Perilaku. Edisi Tujuh,Jilid I Jakarta: Erlangga.

Ghozali. Imam. 2013. Aplikasi Analisis Multivariote dengan Pragram SPSS. BP Universitas Diponegoro. Semarang. 15

Guritno, Bambang dan Waridin. 2005. Pengaruh Persepsi Karyawan Mengenai Perilaku kepemimpinan, Kepuasan Kerja Dan Motivasi Terhadap Kinerja. JRBI.Vol 1. No 1.

Hadi. 2007. Metodologi Research. Yogyakarta: Yayasan Penerbit Fakultas Psikologi Universitas Gajah Mada.

Hair, dkk. 2006. Multivariate Data Analysis. Sixth Edition. New Jersey: Pearson Education.

Hasibuan, Malayu. 2004. Manajemen Sumber Daya Manusia. Jakarta: PT Bumi Aksara.

Hardjono T. 2013. Analisis Pengaruh Motivasi, Disiplin Kerja dan Kemampuan Kerja Terhadap Kinerja Pegawai Negeri Sipil. [Jurnal Tesis] Universitas Dian Nuswantoro. Semarang.

Hasibuan, Malayu Sp. 2003. Organisasi Dan Motivasi; Dasar PeningkatanProduktivitas. Jakarta : PT. Bumi Aksara.

2005. Manejemen SDM Edisi Revisi, Cetakan Ketujuh. Jakarta : PT. Bumi Aksara. 2009. Manajemen Sumber Daya Manusia. Edisi Revisi. Jakarta : Bumi Aksara.

Helmi, Avin Fadilla. 2008. Disiplin Kerja. Buletin Psikologi. Tahun IV, Nomor 2,

Hermanto R. 2015. Pengaruh motivasi kerja dan disiplin kerja terhadap kinerja pegawai pada satuan polisi pamong praja kabupaten Karawang. [Tesis] Universitas Singaperbangsa Karawang.

Malayu.2015. Pengaruh Surfaktan terhadap Residu Minyak. . [Tesis] Institut Pertanian Bogor

Mangkunegara, Anwar A.A, 2010. ManajemenSumber Daya Manusia Perusahaan,Edisi Revisi, Cetakan Kesepuluh,PT Remaja Rosdakarya Offset, Bandung.

Mathis, Robert L. \& John H. Jackson. 2006. Human Resources Management.Jakarta : Salemba Empat.

Moenir, H.A. S,.2002. Manajemen Pelayanan Umum di Indonesia.Jakarta : Bumi Aksara. 
Nawawi, Hadari.2003. Manajemen Sumber Daya Manusia untuk Bisnis yangKompetitif. Yogyakarta : BPFE.

Nitisemito. 2008. Pengelolaan Tentang Kondisi Kerja. Erlangga. Jakarta.

Raditya Priyo, dkk. 2014. Pengaruh Motivasi Kerja Dan Disiplin Kerja

Terhadap Kinerja Karyawan (Studi Kasus Pada PT. Stars International Kota Surabaya). Jurnal Ilmiah Manajemen. Malang: Universitas Brawijaya.

Rivai, Veithzal. 2008. Manajemen Sumber Daya Manusia Untuk Perusahaan.Jakarta:Muri Kencana.

Richard C, Paulus K, dan Johan T. Pengaruh Gaya Kepemimpinan, Motivasi, dan Disiplin Kerja Terhadap Kinerja Karyawan di PT Dayana Cipta. Jurnal Berkala Ilmiah Efisiensi.Volume 15 No 04

Ridwan .2010. Metode dan Teknik Menyusun Tesis. Bandung: Penerbit Alfabeta.

Robbins, P Stephen, 2006. Organizational Behavior (9th Edition), New York: Prentice Hall International.

Santosa, Purbayu Budi dan Ashari. 2005. Analisis Statistik Dengan Ms Excel Dan SPSS. Yogyakarta: ANDI.

Sekaran, Uma. 2006. Metodologi Penelitian Untuk Bisnis. Jakarta: Salemba Empat.

Setiawan. 2013. Pengaruh Disiplin Kerja dan Motivasi Terhadap Kinerja Karyawan pada Rumah Sakit Umum Daerah Kanjuruhan Malang. Jurnal Ilmiah Manajemen. Vol 1 No 4.

Shimko Y. 2012. Pengaruh Gaya Kepemimpinan, Motivasi, dan Lingkungan kerja Terhadap Kinerja Pegawai Negeri Sipil Pada kantor Pemerintah Kabupaten Solok Selatan, Sumater Barat. [Jurnal] Magister Manajemen Vol. 1 No.1. hal 143-174

Simamora, Henry. 2005. Manajemen Sumber Daya Manusia. STIE YKPN. Yogyakarta.

Sidanti H. 2015. Pengaruh Lingkungan Kerja, Disiplin Kerja dan Motivasi Kerja Terhadap Kinerja Pegawai Negeri Sipil di Sekretariat DPRD Kabupaten Madiun. [Jurnal] JIBEKA Volume 9 Nomor 1 Februari 2015: 44-55.

Sri Ainnur YS. 2014. Pengaruh Motivasi Kerja dan Disisplin Kerja Terhadap Kinerja Pegawai Negeri Sipil Melalui Sikap Kerja di Lingkungan Sekretariat DPRD Kabupaten Kudus. [Tesis] Universitas Muria Kudus.

Sugiyono. 2007. Metode Penelitian Administrasi. Bandung: Penerbit Alfabeta.

.2008. Metodologi Penelitian Kuantitatif Kualitatif dan R\&D, edisi keempat Bandung: Alfabeta

Suprayitno, 2007. Pengaruh Disiplin Kerja, Lingkungan Kerja, dan Motivasi terhadap Kinerja Karyawan Sub Dinas Kebersihan dan Tata Kelola DPU dan LLAJ Kabupaten Karanganyar. Jurnal Manajemen Sumberdaya Manusia Vol. 2 No. 1 Desember 342007 : $23-34$. 
Sukmasari H. 2011. Pengaruh Kepemimpinan, Motivasi, Insentif, Lingkungan Kerja, dan Kepuasan Kerja Terhadap Kinerja Pegawai Dinas Pengelolaan Keuangan dan Aset Daerah Kota Semaran

Suranta, Sri. 2002. Dampak Motivasi Karyawan Pada Hubungan Antara Gaya Kepemimpinan Dengan Kinerja Karyawan Perusahaan Bisnis. Empirika. Vol 15. No 2. 